Institute of $\mathbf{F}_{\text {ood and }} \mathbf{A}_{\text {gricultural }} \mathbf{S}_{\text {ciences }}$

\title{
Parenting During the Elementary School Years, Part 2: Discipline ${ }^{1}$
}

\author{
Millie Ferrer, Ingrid Rivera, and Anne M. Fugate ${ }^{2}$
}

\section{Introduction}

\section{As you learned in Part 1 of Parenting During}

the Elementary School Years, your parenting role changes to that of encourager. Your encouragement will help your child discover his interests, strengths, and goals. It will also help him develop a positive and healthy self-concept. However, your role as encourager does not mean that you should not discipline your child when necessary.

A fair, consistent approach to discipline begins with prevention. Using prevention strategies can reduce problems and help create a healthy home environment. This allows your child to become more successful, confident, and happy. A lot can be done to prevent misbehavior. This includes establishing a warm and supportive relationship with your child, letting your child make appropriate choices, and modeling positive behavior. You can also establish rules and consequences and hold family meetings. However, no matter how much effort you put into prevention, your child will still misbehave sometimes. This fact sheet will teach you discipline strategies to use with your child.
The goal of discipline is not to punish, but to teach your child to take responsibility for her actions and to exercise control of her behavior. From infancy through preschool, you begin to teach your child about responsibility and selfcontrol by giving her simple rules and chores, as well as limited choices. Now that your child is in elementary school, he is developmentally ready to understand and practice responsibility and self-control. There are a number of discipline strategies that will help you guide your child's behavior and teach these important skills.

\section{Discipline Strategies}

1. This document is FCS2203, one of a series of the Department of Family, Youth and Community Sciences, Florida Cooperative Extension Service, Institute of Food and Agricultural Sciences, University of Florida. Publication date: September 2002 . Reviewed by Diana Converse FCS Extension Agent and Sharon Treen FCS Extension Agent. Please visit the EDIS Web site at http://edis.ifas.ufl.edu

2. Millie Ferrer, Ph.D., associate professor; Ingrid Rivera, ED.S.,graduate assistant; and Anne M. Fugate, M.Ed. , formner coordinator/education and training program, Department of Family, Youth and Community Sciences, Cooperative Extension Service, Institute of Food and Agricultural Sciences, University of Florida, Gainesville, 32611. 


\section{Share your Reasoning with your Child}

Around the age of seven, your child begins to think more logically. This means that he is better able to make sense of the world around him. This includes the ability to understand your expectations for good behavior and how his behavior affects others. Due to your child's growing ability to think logically, you will be able to use reasons and explanations more often when disciplining him.

However, offering too many explanations may cause you to get into a power struggle with your child. For example, if your child asks for a popsicle before dinner you might say "We are going to eat dinner in 20 minutes. You can have a popsicle for dessert if you want." Because your child is developing the ability to think on his own, he may try to argue the point. If this happens, you may want to repeat your reasoning once and then walk away. By not giving too many explanations, you avoid getting into a power struggle with your child.

\section{Be Firm and Kind}

Being firm does not mean being harsh or rigid. It also does not mean yelling, threatening, or being unkind. Being firm is meaning what you say. It means using a calm tone to let your child know that you are serious about what you want him to do. This strategy can be very effective if it is used consistently. Here are some guidelines to help you use this strategy:

- When you do not want to give your child choices, avoid asking him to do things. For example, do not say "Cameron, are you ready to come to dinner?" Instead, say "Cameron, it is dinner time."

- When you tell your child to do something, he may not like it. It is sometimes difficult for a child to switch activities, so he may feel angry or frustrated. It is important to acknowledge these feelings in an empathetic way. For example, say 'It's frustrating to stop what you're doing when you're having so much fun."

- When you give your child directions, he may argue or plead with you. Avoid arguing with him. This can lead to a power struggle. For example, if Cameron refuses to cooperate the first time, say "Cameron, I know it's frustrating to stop what you're doing, but I need your cooperation. It is dinner time." If Cameron continues to refuse, apply an appropriate consequence.

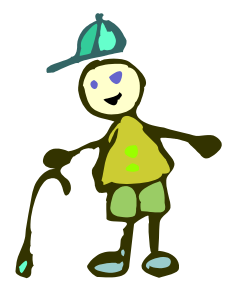

\section{Apply Consequences When Necessary}

As stated in Part 1 of Parenting During the Elementary School Years, parents need to make sure children understand rules and consequences. Then, when a rule is broken, apply the agreedupon consequence. Remember, the consequences you apply need to relate directly to your child's behavior. For example, if the rule is "we take care of our belongings" and your child throws board game pieces across the family room, the consequence is he may not play with the game until the following day.

Always enforce rules consistently. Inconsistency will confuse your child. It teaches her that she can sometimes misbehave without consequence. Follow these simple steps when applying consequences:

- When a rule is broken, calmly remind your child of the rule and apply the appropriate consequence. For example, if Billy borrows his brother's baseball mitt without permission, say "Billy, the rule is we respect each other. This means that we ask 
permission to borrow each other's things. You may not borrow the mitt for one week."

- If the rule continues to be broken, schedule a family meeting to discuss possible solutions to the problem (see Part 1 of Parenting During the Elementary School Years for a description of family meetings).

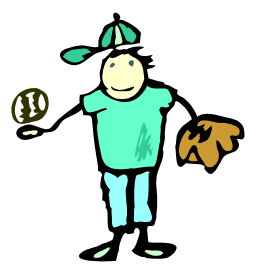

\section{Ignore Misbehavior and Acknowledge Positive Behavior}

Sometimes your child misbehaves simply because he wants your attention, even if it is negative attention. If he misbehaves but is not breaking any rules, such as when he whines or complains, you can ignore his behavior. The behaviors that are ignored will be different from family to family depending on the family's beliefs and values. Below are two guidelines to safely ignoring your child's behavior:

- Be aware of what he is doing and make sure that he is safe.

- Tell your child that you will give him your undivided attention as soon as he stops the unwanted behavior. For example, say "Sam, I will listen to you as soon as you stop complaining about not getting your way."

Ignoring misbehavior lets your child know that his behavior is not appropriate. On the other hand, acknowledging his appropriate behavior reinforces how you would like him to behave. Acknowledging his appropriate behavior will make him feel good about himself. It also teaches him that he does not have to misbehave to get your attention. As a result, misbehavior decreases and appropriate behavior increases. Following are a few tips to help you acknowledge the behaviors you want your child to exhibit:

- Focus on the action, not on your child. Telling him "You are the best!" sets unrealistic expectations that he will not be able to achieve. This type of praise will make your child fearful because he will not want to risk failing.

- Be specific. For example, instead of saying "You are being so good!" say "Carlos, I love the way you are taking turns playing the game with your sister."

- Make it a habit to find at least one positive behavior from your child every day.

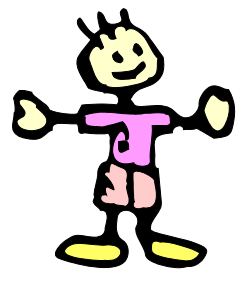

\section{Say "Yes" If Possible}

Instead of simply saying "no" to your child's requests when the timing is not right, try a different approach. For example, if your child asks to play on the computer but she has not finished her homework, say "Yes, Becky, you may play on the computer as soon as you finish your homework." This teaches her that there is an appropriate time to do different activities.

\section{Call a Break}

A break is a time for your child to calm down when she is angry or frustrated. It is very important for you to remain calm when you tell your child to take a break. This strategy is not meant to be a punishment. Call a break when you notice your child needs it and not out of your own anger or frustration. When used correctly, many children feel the benefits of taking a break and may take one on their own when they feel they are losing self-control. 
When you notice your child needs a break, acknowledge her feelings in a calm manner and tell her that she needs a break. For example, say "Christy, I can see that you are very angry right now. You will feel better after taking a break." Allow your child to choose where in the house she would like to go to cool off. Your child may choose to go to her room or to the backyard. This choice makes children feel like they have some control over the situation, which may help them calm down more easily and quickly.

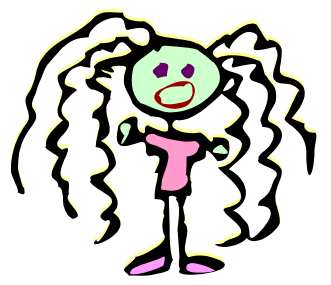

\section{Special Challenges During the School- Age Years}

You may run into some challenging behaviors with your elementary school-age child. It is important to keep in mind that these behaviors are common to this age group. Just because your child exhibits some of these behaviors does not mean that she is a bad child or that you are a bad parent. Some of these challenging behaviors involve homework, television, sibling rivalry, chores, and lying. This section focuses on ways to address these issues with your child.

\section{Homework}

Some children dread the thought of doing homework. They may leave an assignment for the last minute or refuse to do it all together. Many parents handle this by trying to force their children to do their homework. However, getting into a power struggle with your child is not effective. By having clear rules and expectations, you can create a positive situation for both you and your child. Following are some suggestions to help you with homework situations:
- Have a set time for your child to do homework. Then, make sure to provide a quiet atmosphere during this time. It is easier for your child to stay on task if you do not distract her by watching television and talking on the telephone.

- Make yourself available during homework time, but do not do her work even if she leaves a project for the last minute. In that case, acknowledge her frustration. Avoid lecturing and telling her "I told you so."

- Avoid constantly nagging or lecturing your child to do homework. If your child is continuously frustrated by or unable to complete assignments, visit your child's teacher. Discuss ideas to work out possible strategies to help your child succeed.

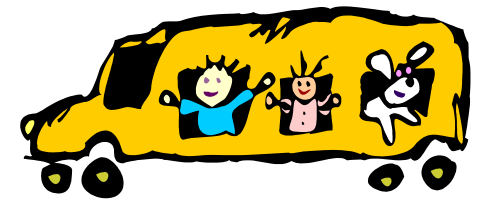

\section{Television}

Television viewing can have both positive and negative effects. Many people like to watch TV because it is entertaining or educational. However, watching TV can become an addiction. This addiction can then lead to negative behavior changes in viewers. It has been found that watching too much TV can negatively affect children's health and behavior.

The following are tips to help you monitor television viewing in your home:

- Decide which shows you do not want your child to watch.

- Limit the amount of time spent watching TV Help your child find alternatives to watching TV such as inviting a friend to come over to play, working on an art project, reading, or doing something together as a family. 
- Help your children reach a compromise about how they will share or divide viewing time. This can be discussed during family meetings.

\section{Sibling Rivalry}

Sibling rivalry is a normal part of growing up. Siblings argue about many things. Do not feel

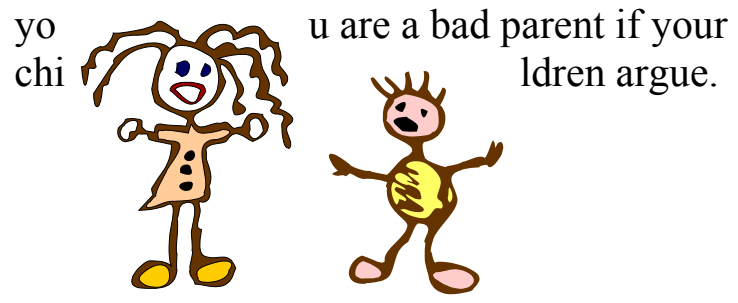

In most cases, children can solve their disagreements with siblings if they are taught a few simple guidelines. Instead of rescuing your children when they are arguing, help them to get along better with each other. Teaching your children to resolve arguments will allow them to become more socially competent. Here are some guidelines to teach your children to solve problems:

- When you know your children are capable of solving the problem, avoid getting involved in their conflicts. When you get involved in your children's conflicts, they become dependent on you to solve their arguments.

- Do not allow your children to argue in front of you. Ask your children to argue elsewhere by saying "I'm sorry to hear you are upset with each other, but if you are going to argue, take it where I can't hear you."

- If you notice that your children are unable to reach a compromise, step in and coach them. First, make sure that they can state the problem. Then ask them what they need to do to solve it. After the children list several suggestions, ask them to agree on a solution. If both children agree on a safe solution, allow them to use it.

In general, parents should not get involved in children's conflicts, but they must when arguments get physical. This is called sibling abuse. Sibling abuse includes behavior such as hitting, biting, or kicking a sibling. Parents should not allow this to occur under any circumstances. If you see siblings hitting each other, stop the behavior immediately and firmly remind them of your expectations about how to treat others. To reinforce your expectations, at your next family meeting review the household rules and the consequences for breaking them. In certain circumstances, families may need to seek professional help to address the problem. The following are signs that sibling abuse is occurring:

- A child constantly avoids a sibling

- A child has nightmares, a change in sleep patterns, or a change in eating habits

- A child acts out abuse through play

\section{Chores}

It is important to assign your child chores to do in the home. Chores give children a sense of responsibility, pride, and competence. Although it is normal for your child to avoid doing the household chores at times, this does not mean that she should not to do them. The tips to help you get involved with the chores:

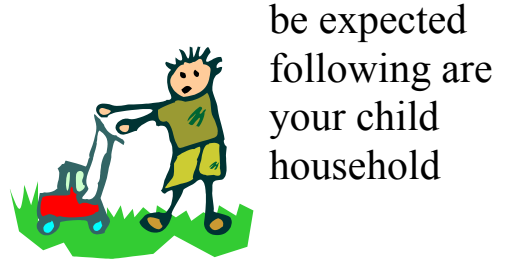

- Use the family meeting to involve your child in developing a list of chores that need to be done on a daily and weekly basis. 
- As a family, decide how the chores will be assigned each week and the consequences for not doing them. For example, you may choose to draw chores out of a hat or rotate chores from week to week.

- Together, decide on a specific day and time to do the weekly household chores.

- Instead of nagging your child to do her chores, tell her to look at the chore list to see what she is responsible for that week.

\section{Lying}

Children lie for a variety of reasons. Often, children prefer to lie than to face the consequences of making a mistake. They may feel safer telling a lie than risking angering their parents or feeling rejected. Some children lie because they think others will like them more if they pretend to be someone they are not. The suggestions below will allow you to deal with lying in a sensitive and effective way:

- Model a positive attitude towards mistakes. If your child learns that everyone makes mistakes on occasion, she will be less likely to lie when she makes a mistake.

- Make your child feel loved and special. She will realize that she does not have to lie to be loved because you love her just as she is.

- Avoid asking questions about your child's behavior that you already know the answer to. This may cause your child to lie to avoid getting in trouble.

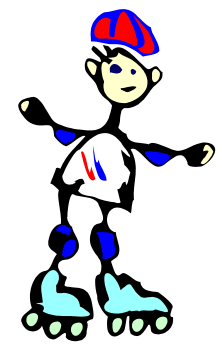

\section{Practice What You've Learned}

Now that you have learned some prevention and discipline strategies to use with your school-age child, practice what you've learned.

$\square$ Look at Table 1: Practice Exercise on page 8. Column one lists some typical situations you may experience with your child. Read the situation and decide how you would handle it. Then, think of what you can do to prevent future misbehavior. Refer to Part 1 of Parenting During the Elementary School Years for suggestions.

Finally, look at Table 2 on page 9 for possible responses.

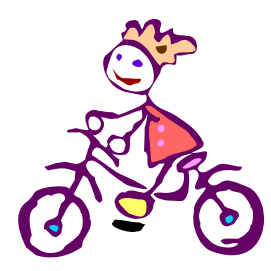

\section{Conclusion}

The discipline strategies discussed in this fact sheet can be used to deal with your child's misbehavior quickly and effectively. However, behavior management does not end with taking care of an incident. Prevention is the key to decreasing misbehavior. If you take the time to prevent misbehavior and discipline your child when necessary, you will help him become more responsible, happy, and self-confident.

It takes time to see changes in your child's behavior. However, if you have tried these discipline strategies consistently for a while and do not see changes in your child's behavior, seek professional guidance.

\section{References}

Allen, R. 1998. How to guide a child's misbehavior. Retrieved February 8, 2002 from University of Minnesota Extension Service Web site: http://www.extension.umn.edu/infou/families/BE706.html 
Better Kid Care Project. 1996. Better kid care: Getting children to follow rules. Retrieved on February 5, 2002 from National Network for Child Care Web site: http://www.nncc.org/Guidance/better.rules.html.

DeBord, K. 1996. Appropriate limits for young children: A guide for discipline, part 2. Retrieved on January 23, 2002 from National Network for Child Care Web site: http://www.nncc.org/Guidance/limits2.html.

Ferrer, M. and McCrea, S. 1999. Sibling rivalry. Retrieved January 11, 2002 from University of Florida Extension EDIS Web site: http://edis.ifas.ufl.edu.

Ferrer, M., Rivera, I., and Fugate, A. 2002. Working with school-age children, part 2: Discipline. Available from University of Florida Extension EDIS Web site: http://edis.ifas.ufl.edu.
Steffens, P. 1995. Positive approach to discipline. Retrieved February 8, 2002 from Cooperative Extension, Institute of Agriculture and Natural Resources, University of Nebraska-Lincoln Web site: http://www.ianr.unl.edu/pubs/family/g1190.htm.

Telep, V. 1999 Discipline for young children. Retrieved on January 28, 2002 from Virginia Cooperative Extension Web site: http://www.ext.vt.edu/pubs/ family/350-112/350-112.html

Wilson, E. 2000. Guiding young children series: Responses to misbehavior. Retrieved on January 28, 2002 from Oklahoma Cooperative Extension Service Web site: http://agweb.okstate.edu/pearl/fci/family/t2327.html. 
Table 1: Practice Exercise

\begin{tabular}{|c|c|c|}
\hline Scenario & Immediate Action & Future Prevention Strategy \\
\hline \multicolumn{3}{|l|}{$\begin{array}{l}\text { Your child, Chloe, comes home from school } \\
\text { with an unfamiliar bracelet. She tells you that } \\
\text { her friend, Jennifer gave it to her. Later that } \\
\text { night, you receive a call from Jennifer's mother } \\
\text { saying that Chloe took Jennifer's bracelet. }\end{array}$} \\
\hline \multicolumn{3}{|l|}{$\begin{array}{l}\text { Your daughters, Janice and Cathy, are setting } \\
\text { up a board game. You hear them argue about } \\
\text { who will go first. }\end{array}$} \\
\hline \multicolumn{3}{|l|}{$\begin{array}{l}\text { During a family board game your son, Jason, } \\
\text { gets upset because he is losing. }\end{array}$} \\
\hline \multicolumn{3}{|l|}{$\begin{array}{l}\text { One of your family rules is that the family eats } \\
\text { dinner together at } 6: 30 \text {. Your son, Charlie, is } 15 \\
\text { minutes late for dinner. }\end{array}$} \\
\hline $\begin{array}{l}\text { One of your child's chores is to take out the } \\
\text { garbage. Jamie, your daughter, asks you if she } \\
\text { can go over to a friend's house but you notice } \\
\text { that she has not done her chore. }\end{array}$ & & \\
\hline
\end{tabular}


Table 2: Practice Exercise

\begin{tabular}{|c|c|c|}
\hline Scenario & Immediate Action & Future Prevention Strategy \\
\hline $\begin{array}{l}\text { Your child, Chloe, comes home from school } \\
\text { with an unfamiliar bracelet. She tells you that } \\
\text { her friend, Jennifer gave it to her. Later that } \\
\text { night, you receive a call from Jennifer's mother } \\
\text { saying that Chloe took Jennifer's bracelet. }\end{array}$ & $\begin{array}{l}\text { Tell Chloe what Jennifer's mother said and ask } \\
\text { her if there has been a misunderstanding } \\
\text { between her and Jennifer. If Chloe continues to } \\
\text { insist that Jennifer gave her the bracelet, accept } \\
\text { her answer because neither you nor Jennifer's } \\
\text { mother were there to witness what happened. } \\
\text { However, tell Chloe that even though Jennifer } \\
\text { gave her the bracelet, it needs to be returned. }\end{array}$ & $\begin{array}{l}\text { Establish a family rule such as "we only take } \\
\text { school -related items to and from school." If } \\
\text { your family already has such a rule, review it } \\
\text { with your child. }\end{array}$ \\
\hline $\begin{array}{l}\text { Your daughters, Janice and Cathy, are setting } \\
\text { up a board game. You hear them argue about } \\
\text { who will go first. }\end{array}$ & $\begin{array}{l}\text { If you see that they are trying to find a solution } \\
\text { on their own, do not get involved. However, if } \\
\text { the situation is getting out of control, take } \\
\text { action. Coach the children on how to find a } \\
\text { solution. }\end{array}$ & $\begin{array}{l}\text { Continue to coach problem-solving techniques } \\
\text { until your child/ren practice them on their own. }\end{array}$ \\
\hline $\begin{array}{l}\text { During a family board game your son, Jason, } \\
\text { gets upset because he is losing. }\end{array}$ & $\begin{array}{l}\text { Remind him that you are all playing the game for } \\
\text { fun. If he continues to get angry, reflect his feeling } \\
\text { and tell him to take a break. For example, say } \\
\text { "Jason, I can tell that you are very upset right now. } \\
\text { Take a break." }\end{array}$ & $\begin{array}{l}\text { The next time you decide to play a game, remind } \\
\text { him that you are playing for fun and that you } \\
\text { expect him to be a good sport. }\end{array}$ \\
\hline $\begin{array}{l}\text { One of your family rules is that the family eats } \\
\text { dinner together at } 6: 30 \text {. Your son, Charlie, is } 15 \\
\text { minutes late for dinner. }\end{array}$ & $\begin{array}{l}\text { If this is the first time that Charlie is late for dinner, } \\
\text { tell him how you feel (e.g. frustrated, worried, } \\
\text { annoyed) and remind him of the family rule. }\end{array}$ & $\begin{array}{l}\text { If your child continues to be late for dinner, discuss } \\
\text { possible solutions to the problem at your next } \\
\text { family meeting. For example, a possible solution } \\
\text { may be that whoever is late for dinner must clean } \\
\text { up the kitchen by himself. }\end{array}$ \\
\hline $\begin{array}{l}\text { One of your child's chores is to take out the } \\
\text { garbage. Jamie, your daughter, asks you if she } \\
\text { can go over to a friend's house but you notice } \\
\text { that she has not done her chore. }\end{array}$ & $\begin{array}{l}\text { Tell Jamie that she can go to her friend's house as } \\
\text { soon as she takes out the garbage. }\end{array}$ & $\begin{array}{l}\text { Nagging is not effective. This will lead to a power } \\
\text { struggle with your child. Instead, remind her of the } \\
\text { expectation that every family member cooperates } \\
\text { in the house by doing chores. }\end{array}$ \\
\hline
\end{tabular}

